\title{
Estimation of cardiosurgical intervention risk according to EuroSCORE in patients with acute coronary syndrome and different gallbladder conditions before coronary artery bypass grafting
}

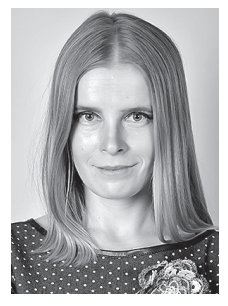

\author{
Larysa Strilchuk ${ }^{1}$, Dmytro Besh ${ }^{2}$ \\ ${ }^{1}$ Department of Therapy and Medical Diagnostics, Lviv National Medical University named after Danylo Halytsky, Lviv, Ukraine \\ ${ }^{2}$ Department of Family Medicine, Lviv National Medical University named after Danylo Halytsky, Lviv, Ukraine
}

Kardiochirurgia i Torakochirurgia Polska 2018; 15 (4): 238-240

\begin{abstract}
Introduction: Estimation of cardiosurgical intervention risk according to EuroSCORE is an important aspect of cardiosurgery. EuroSCORE allows prediction of the probability of a post-operational fatal outcome.

Aim: To estimate the influence of gallbladder condition on the prognosis after coronary artery bypass grafting (CABG) and and the interactions between metabolic background and cardiosurgical intervention risk.

Material and methods: We investigated data of 98 patients with unstable angina pectoris or acute myocardial infarction before planned CABG. These patients were divided into the following groups according to their gallbladder condition: intact bladder; bile sludge or cholesterosis; bent gallbladder body; gallbladder neck deformations or cholecystitis; cholelithiasis; history of cholecystectomy.

Results: The mean cardiosurgical intervention risk score according to the EuroSCORE system in our patients was 6.03 $\pm 0.62 \%$. It was significantly higher in patients with low serum bilirubin levels. There were direct correlations between the risk score result and presence of left ventricular dilatation $(r=0.31$, $p<0.05)$ and fasting glucose level $(r=0.82, p<0.01)$, as well as with means of other parameters, i.e., left atrial dimension, right ventricular size, grade of stenosis of anterior interventricular branch of left coronary artery, serum levels of total cholesterol, $\beta$-lipoproteins, bilirubin and potassium.

Conclusions: These correlations suggest that the EuroSCORE results estimated before surgery may be used as a simple informative prognostic criterion of intra-operational cardiac mortality and also as a marker of structural and functional heart condition and metabolic background. However, these correlations were different in patients with different gallbladder conditions.
\end{abstract}

Key words: cardiosurgical intervention risk, EuroSCORE, gallbladder.

\section{Streszczenie}

Wprowadzenie: Ocena ryzyka interwencji kardiochirurgicznej w skali EuroSCORE stanowi ważne zagadnienie w kardiochirurgii. Skala EuroSCORE pozwala przewidzieć prawdopodobieństwo zgonu po operacji.

Cel: Ocena wpływu choroby pęcherzyka żótciowego na prognozy po operacji pomostowania aortalno-wieńcowego (CABG) oraz zależności między stanem metabolicznym a ryzykiem interwencji kardiochirurgicznej.

Materiał i metody: W badaniu wzięło udział 98 pacjentów z niestabilną dławicą piersiową lub zawałem serca przed planowaną operacją CABG. Pacjentów podzielono na grupy według stanu pęcherzyka żółciowego: niezmieniony pęcherzyk, zastój żółci lub cholestaza, zagięty pęcherzyk żółciowy, deformacje szyi pęcherzyka żółciowego lub zapalenie pęcherzyka żółciowego, kamica żółciowa, cholecystektomia.

Wyniki: Ryzyko przeprowadzenia interwencji kardiochirurgicznej zgodnie ze skalą EuroSCORE u pacjentów wynosito średnio $6,03 \pm 0,62 \%$. Było ono istotnie wyższe u pacjentów z małym stężeniem bilirubiny $w$ surowicy. Stwierdzono bezpośredni związek między wynikiem oceny ryzyka a występowaniem dylatacji lewej komory $(r=0,31, p<0,05)$, stężeniem glukozy na czczo ( $r=0,82, p<0,01)$, a także średnimi wartościami innych parametrów, takich jak wymiar lewego przedsionka, wielkość prawego przedsionka, stopień stenozy gałęzi międzykomorowej przedniej lewej tętnicy wieńcowej, stężenie cholesterolu całkowitego w surowicy, $\beta$-lipoprotein, bilirubiny i potasu.

Wnioski: Współzależności sugerują, że wyniki EuroSCORE uzyskane przed operacją mogą stanowić proste kryterium prognostyczne śródoperacyjnej śmiertelności z przyczyn sercowych, a także marker stanu strukturalnego i funkcjonalnego serca oraz stanu metabolicznego. Zależności te były jednak różne u pacjentów z odmiennymi chorobami pęcherzyka żółciowego.

Słowa kluczowe: ryzyko interwencji kardiochirurgicznej, skala EuroSCORE, pęcherzyk żółciowy.

Address for correspondence: Larysa Strilchuk PhD, Department of Therapy and Medical Diagnostics, Lviv National Medical University named after Danylo Halytsky, 69 Pekarska St, 79000 Lviv, Ukraine, e-mail: larysa.stril4uk@ukr.net

Received: 3.12.2017, accepted: 10.03.2018. 


\section{Introduction}

Estimation of cardiosurgical intervention risk, which allows prediction of post-operational mortality, is an important aspect of modern cardiology and cardiosurgery. The European System for Cardiac Operative Risk Evaluation (EuroSCORE) and Cardiac Anesthesia Risk Evaluation (CARE) were proposed in the middle 1990s for predicting mortality after cardiac surgery [1]. EuroSCORE (http://euroscore.org) estimates three groups of factors: 1) patientrelated factors: age and sex; presence of chronic pulmonary diseases, extracardiac arteriopathy (i.e., carotid arteries or aorta), diseases with neurological dysfunction; previous cardiac surgery with pericardium opening; serum creatinine level before intervention $>200 \mu \mathrm{mol} / \mathrm{l}$; presence of active endocarditis or critical condition (ventricular tachycardia or fibrillation, history of sudden cardiac death, indirect heart massage before intervention, pre-operational artificial lung ventilation, usage of inotropic agents before intervention, intra-aortic balloon pump counterpulsation, and pre-operational acute kidney failure); 2) heart-related factors: unstable angina pectoris, left ventricular dysfunction, myocardial infarction within last 90 days, pulmonary hypertension; 3) operation-related factors: urgent intervention, surgery of thoracic aorta, other intracardiac procedures, post-infarction septal rupture. Some modifications of this scoring system have been proposed, e.g., logistic, EuroSCORE II. For instance, the scale named EuroSCORE II (2011) also includes (1) - poor mobility, creatinine clearance instead of serum creatinine level, presence of diabetes mellitus with insulin usage; (2) - functional classes of angina and heart failure according to New York Heart Association classification; (3) - intervention significance. But not all scientists agree on its advantages.

Although some authors state that EuroSCORE is not precise in prognosis prediction [2] and provides inflated rates of mortality [3, 4], it continues to be a gold standard for European heart surgery. EuroSCORE can be used just near the patient's bed without any complicated calculations or digital technologies. The logistic model of EuroSCORE better predicts risk, especially in patients with high cardiovascular risk, and therefore it is of special interest for scientific investigations or risk stratification planning $[5,6]$.

It is widely known that ischemic heart disease and gallbladder disorders are widespread pathological conditions with mutual pathogenetic mechanisms [7] and risk factors. Analysis of data of 841 patients who underwent cholecystectomy due to cholelithiasis showed that patients with cholesterol gallstones had 50\% lower risk of stroke-related mortality, but an increased risk of ischemic heart disease [8]. The influence of gallbladder condition on prognosis of cardiosurgical intervention consequences was not studied before, and this fact determined the importance and novelty of this work.

\section{Aim}

The aim of this paper was to investigate correlations of risk after coronary artery bypass grafting (CABG) according to the EuroSCORE scale in patients with unstable angina pectoris or acute myocardial infarction and different gallbladder conditions.

\section{Material and methods}

Cardiosurgical intervention risk was estimated with the help of the EuroSCORE calculator (http://EuroSCORE. org) in 98 patients with acute coronary syndrome before CABG (40\% with acute ST-elevation myocardial infarction, $60 \%$ with unstable angina pectoris; $79 \%$ male, $21 \%$ female; mean age: $61.7 \pm 1.6$ years). These patients were then divided into the following groups according to gallbladder condition: intact bladder - 29; sludge and cholesterosis - 13; bent gallbladder body - 13; gallbladder neck deformations and cholecystitis - 27; cholelithiasis - 11; prior cholecystectomy - 5 persons. Diagnostics and treatment were performed according to Decrees of Ministry of Health of Ukraine No. 436 dated 03.07.2006 and No. 816 dated 23.11.2011, using standard methods. The work was carried out according to the Declaration of Helsinki and approved by the local Ethics Committee.

\section{Statistical analysis}

Digital data were processed with the help of Statistica 6.0 software (USA); correlation analysis of 35 clinical, laboratory and instrumental parameters was performed using Pearson's method; results were considered statistically significant if the $p$-value was $<0.05$.

\section{Results and discussion}

It was found that in investigated patients the cardiosurgical intervention risk score varied between $1.33 \%$ and $48.4 \%$. The mean value was $6.03 \pm 0.62 \%$, which exceeds the results of 42 investigations on cardiac surgery, involving 213283 patients, but was lower than the cardiosurgical intervention risk score in 8 other investigations, involving 8440 patients [5]. Gallbladder condition did not significantly influence the risk, although minimal mean values were revealed in patients with intact gallbladder and gallbladder neck deformations (5.54\% and $4.85 \%$, respectively), whereas maximal mean values were observed in those with cholelithiasis, sludge and cholesterosis $(6.69 \%$ and $9.56 \%$, respectively).

As bilirubin is considered to be a potent endogenous antioxidant with anti-atherogenic properties and a positive influence on lipid metabolism along with an anti-thrombotic action [9], we compared cardiosurgical intervention risk scores in patients with serum bilirubin level below and above $10.0 \mu \mathrm{mol} / \mathrm{l}$ (accordingly, $65.3 \%$ and $34.7 \%$ of patients; these subgroups had comparative mean values of age and body weight, gender ratio and diagnosis). Although liver function is not mirrored in the EuroSCORE system, it was revealed that in the case of a low total serum bilirubin level the risk score was significantly higher $(6.18 \pm 0.93 \%$ vs. $3.55 \pm 0.83 \%$ in the subgroup with serum bilirubin levels $>10 \mu \mathrm{mol} / \mathrm{l}, p<0.05$ ). 


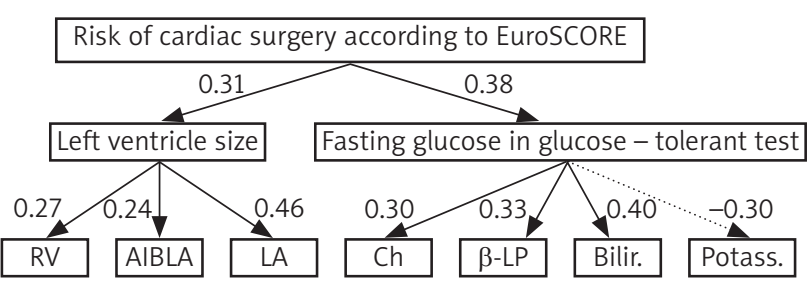

RV - right ventricular size, AIBLA - anterior interventricular branch of the left coronary artery, LA - left atrial diameter, Ch - total serum cholesterol, $\beta$-LP serum $\beta$-lipoproteins, bilir. - total serum bilirubin, potass. - serum potassium. Solid line means direct correlation, dotted line - indirect correlation.

Fig. 1. Significant correlations of cardiac surgery risk score, structural and functional cardiac parameters and metabolic disorders

According to correlation analysis, in all patients cardiosurgical intervention risk score directly correlated with end-diastolic left ventricular diameter $(r=0.31, p<0.05)$ and fasting glucose level during the glucose tolerance test $(r=0.38, p<0.05)$. Thus, increased cardiosurgical intervention risk is closely associated with left ventricular dilatation and increased fasting glucose, although the EuroSCORE system includes only systolic dysfunction, NYHA functional class of heart failure, and overt diabetes mellitus with insulin use. So, high cardiosurgical intervention risk score is quite a sensitive marker of structural heart changes and disorders of glucose metabolism.

Other correlations, presented in Figure 1, show that increased cardiosurgical intervention risk goes in parallel not only with the left ventricular enlargement, but also with the increased left atrial size (meaning diastolic dysfunction), right ventricular size (meaning severe biventricular heart failure), and grade of stenosis of the anterior interventricular branch of the left coronary artery, which provides about $40 \%$ of left ventricular blood supply. Speaking of metabolic disorders, increased cardiosurgical intervention risk is associated with elevated serum levels of fasting glucose, total cholesterol, $\beta$-lipoproteins, total bilirubin and decreased serum potassium level, playing an important role in the pathogenesis of arrhythmias, QT interval prolongation and progression of heart failure [10].

At the same time, cardiosurgical intervention risk score correlations differed in patients with various gallbladder conditions. For instance, in patients with an intact gallbladder, cardiosurgical intervention risk score directly correlated only with age $(r=0.57, p<0.05)$, and in patients with sludge and gallbladder cholesterosis it correlated with fasting glucose level $(r=0.82, p<0.01)$. In those with a bent gallbladder body cardiosurgical intervention risk score was directly associated with the sizes of left ( $r=0.75$, $p<0.05)$ and right $(r=0.69, p<0.05)$ ventricles and also left atrial diameter $(r=0.66, p<0.05)$. In patients with gallbladder neck deformations, which usually result from chronic cholecystitis and frequently cause bile flow obstruction, cardiosurgical intervention risk score correlated with patients' age $(r=0.47, p<0.05)$, white blood cell count $(r=0.40, p<0.05)$, and serum potassium level $(r=-0.41$, $p<0.05)$. Only in the group with cholelithiasis was cardiosurgical intervention risk was proportional to the duration of in-patient treatment $(r=0.83, p<0.05)$, and in persons with removed gallbladder - to aspartate aminotransferase activity $(r=0.94, p<0.05)$.

This study has some limitations: the small group size and no control group consisting of healthy people.

\section{Conclusions}

Mean risk of surgical intervention according to EuroSCORE in 98 patients with acute coronary syndrome, who underwent coronary artery bypass grafting, was $6.03 \pm 0.62 \%$ and was significantly higher in persons with a low serum bilirubin level. Estimated risk directly correlated with left ventricular size dilatation and serum fasting glucose levels, and with the means of other correlations, e.g., left atrial and right ventricular sizes, grade of stenosis of anterior interventricular branch of the left coronary artery, serum levels of total cholesterol, $\beta$-lipoproteins, bilirubin and potassium. These correlations suggest that cardiosurgical intervention risk score may be used as a simple informative criterion of prognosis of intra-operational cardiac mortality and also as a marker of structural and functional heart condition and metabolic disorders. Correlations of cardiosurgical intervention risk score differed in patients with different gallbladder conditions. Future perspectives of related investigations include the use of EuroSCORE for screening of other consequences of cardiosurgical interventions apart from mortality.

\section{Disclosure}

The authors report no conflict of interest.

\section{References}

1. Howell NJ, Head SJ, Freemantle N, van der Meulen TA, Senanayake E, Menon A, Kappetein AP, Pagano D. The new EuroSCORE II does not improve prediction of mortality in high-risk patients undergoing cardiac surgery: a collaborative analysis of two European centres. Eur J Cardiothorac Surg 2013; 44: 1006-1011.

2. Margaryan R, Moscarelli M, Gasbarri T, Bianchi G, Kallushi E, Cerillo AG, Farneti $P$, Solinas $M$. The EuroSCORE performance in minimally invasive cardiac surgery: discrimination ability and external calibration. Innovations (Phila) 2017; 12: 282-286.

3. Siregar S, Groenwold RH, de Heer F, Bots ML, van der Graaf Y, van Herwerden LA. Performance of the original EuroSCORE. Eur J Cardiothorac Surg 2012; 41: 746-754.

4. Tran DT, Dupuis JY, Mesana T, Ruel M, Nathan HJ. Comparison of the EuroSCORE and CARE score for risk-adjusted mortality analysis in cardiac surgery. Eur J Cardiothorac Surg 2012; 41: 307-313.

5. Guida P, Mastro F, Scrascia G, Whitlock R, Paparella D. Performance of the EuroSCORE II: a meta-analysis of 22 studies involving 145,592 cardiac surgery procedures. J Thorac Cardiovasc Surg 2014; 148: 3049-3057.

6. Michel P, Roques F, Nashef SA. Logistic or additive EuroSCORE for high-risk patients? Eur J Cardiothorac Surg 2003; 23: 684-687.

7. González-Pérez A, García Rodríguez LA. Gallbladder disease in the general population: association with cardiovascular morbidity and therapy. Pharmacoepidemiol Drug Saf 2007; 16: 524-531.

8. Kono S, Ichimiya H, Tokudome S, Ikeda M, Nakayama F. Type of gallstones and deaths from stroke and coronary heart disease among cholecystectomized patients. Int J Epidemiol 1988; 17: 82-85.

9. Vitek L. Bilirubin and atherosclerotic diseases. Physiol Res 2017; 66 (Suppl. 1): S11-S20.

10. Hoss S, Elizur Y, Luria D, Keren A, Lotan C, Gotsman I. Serum potassium levels and outcome in patients with chronic heart failure. Am J Cardiol 2016; 118: 1868-1874. 